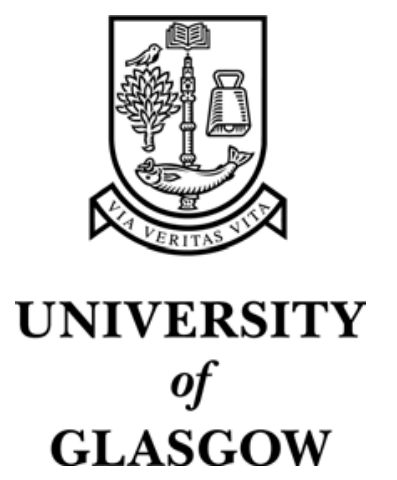

Beattie, V. (2005) Moving the Financial Accounting Research Front

Forward: The UK Contribution. British Accounting Review 37(1):85-114.

http://eprints.gla.ac.uk/archive/00000737/ 


\title{
Moving the Financial Accounting Research Front Forward: The UK Contribution
}

\author{
Vivien Beattie \\ University of Glasgow
}

Draft date: August 2004

Correspondence details

Professor Vivien Beattie

Department of Accounting and Finance

University of Glasgow

65-73 Southpark Avenue

Glasgow

G12 8LE

Tel. 01413306855 (direct line) 5666 (department)

Email V.Beattie@accfin.gla.ac.uk

\section{Acknowledgements}

This paper has benefited greatly from the comments of two anonymous $B A R$ reviewers. 


\title{
Moving the Financial Accounting Research Front Forward: The UK Contribution
}

\begin{abstract}
The purpose of this paper is to review the recent UK contribution to the field of financial accounting research, set against the backdrop of the global (mainly US) research effort. A systematic overview of recent research in the field is presented, based upon an analysis of 261 articles published between 1998 and 2002 in seven general, non-US journals. These are the journals that UK academics publish in most frequently and 115 of the articles are UK-authored. It is found that the research areas of MBAR and disclosure currently dominate conventional financial accounting research. The comparison of findings across institutional settings offers fruitful lines of inquiry for research within these main areas (i.e. studies of value relevance, analysts' forecasts, voluntary disclosure and earnings management). While most research is seen to follow the highly quantitative, economics-based US tradition, a significant amount of UK research adopts a more qualitative approach, and distinctive UK contributions are evident in a number of areas (in particular, the disclosure process and corporate social reporting). There are signs that UK researchers are helping researchers in other countries contribute to the global body of scholarly knowledge.
\end{abstract}

Keywords: analytical; archival; case-based research; disclosure, earnings management; experimental; graphs; MBAR; narratives, normative, survey; research areas; research front; review; standard setting. 


\section{Moving the Financial Accounting Research Front Forward: The UK Contribution}

\section{INTRODUCTION}

This article undertakes a review of the current state of academic research in the field of financial accounting. Financial accounting is one of the main fields within the accounting discipline and it encompasses many distinct research areas. Given that this review is constrained to the length of a journal article, the discussion must inevitably be relatively high level. This article is one of a set of such articles, each covering a different field, which has been commissioned by the editors of the British Accounting Review. Since other reviews will deal with international accounting and critical accounting, and possibly accounting history, these areas are specifically excluded from this review. However, the subject boundaries are not clear cut, as financial accounting has links with fields such as audit, corporate governance, management accounting and not-for-profit organisations. These specialist areas are also excluded from this review.

Review articles can serve a number of purposes. Given that this review covers an entire field, it presents an overview and, therefore, to some extent depth is sacrificed for breadth of coverage. The primary intended audience is academics at the outset of their research career. The review offers such individuals a point of entry to the theories, research methods, key prior and current literature in a particular area. Secondary audiences are advanced level students and established academics with a thorough knowledge of a given sub-field. By mapping out the domain of a field, a broad review provides a useful aid to teachers seeking to provide a broad overview to students, acting as an 'advance organiser' to encourage integrated learning (Mayer, 1987, pp.120-125). Broad reviews allow researchers experienced in the field to take stock; to evaluate progress and identify gaps and fruitful lines for future inquiry.

The brief was to focus on the contribution made by conventional ${ }^{1}$ financial accounting researchers in the UK over recent years. ${ }^{2}$ This contribution is set against the backdrop of research developments elsewhere, particularly in the US and continental Europe. Since the accounting literature is truly global, it is unhelpful to try to discuss the UK 
contribution without recognizing the linkages that the UK research effort has with non-UK research. Global research is the context within with UK researchers seek to make a contribution.

All reviews of this type are necessarily personal and subjective. However, to guard against an unduly unbalanced and impressionistic evaluation, this review is grounded in a systematic analysis of contemporary UK contributions. The scholarly communication literature identifies the academic journal as the primary medium of scholarly discourse (Borgman, 1990). ${ }^{3}$ In the discipline of accounting, academic (i.e., peer-reviewed) journals accounted for $52 \%$ of all publication outputs by UK and Irish academics during 1998 and 1999 (Beattie and Goodacre, 2004, Table 2). Professional journal articles, books, book chapters and research reports account for a most of the remainder. However, most original research is reported in the academic journal literature, even if it is also reported in other publication media as well (albeit written in a different style for a different audience). This is one of the main reasons why the systematic review confines itself to academic journals (the other reason is that it was necessary to keep the task to manageable proportions). However, the more subjective, narrative review does include selected books and research reports.

Academic journal publications are highly concentrated in accounting. Beattie \& Goodacre (2004) report that, over a two year period, 1,141 articles were published spread across 442 different journals (p.25). However the top ten accounting journals accounted for $57 \%$ of all publications in accounting journals. These journals were systematically examined to identify financial accounting articles, examine the characteristics of these articles and assess their contribution. A total of 261 articles, published between 1998 and 2002, were evaluated.

Rather than simply document the development of financial accounting research, this article seeks to offer some explanation of the current structure of the field. The sociology of scientific knowledge and scholarly communication literatures examine the development of scholarly knowledge and the academic evaluation and reward system that underpins the production of this knowledge. Scholarship is understood to constitute a social system. Often developments emerge from the interplay of three sources of influence: external influences, internal cognitive (i.e. intellectual) factors and internal 
social factors (Borgman, 1990; Woolgar, 1988). Because financial accounting is a social science discipline with practical application, it is especially open to influence from the outside. External events can shift research priorities and create new research areas, helping to keep the field fresh and exciting.

Developments can also occur due to internal factors, whether cognitive or social in nature. Obviously, there can be intellectual breakthoughs (minor or major). Such cognitive aspects are traced through published research documents, which are the formal output of scholarly activity and the formal channel for the communication of ideas. The social dynamics of the global academic accounting community (i.e. its structures and processes), as well as its evaluation and reward structures, can also exert a powerful influence. The social aspects of scholarly communication are captured by the 'invisible college' concept (Crane, 1972). The social structure of academic communities arises from the different types of social relationship that can exist between scholars: coauthorship, trusted assessorship, colleagueship; and apprenticeship (Mullins, 1973). In particular, this review documents the co-authorship relationships between UK and continental European academics.

The remainder of this paper is structured as follows. Section two briefly considers the historical development of financial accounting research and the reasons why developments in research occur, distinguishing between external influences, internal cognitive factors and internal social factors. In section three, the journals and articles that were specifically reviewed for the purposes of writing this paper are described. The main review is contained in section four, which presents the quantitative findings from the analysis of recent research published in the field and then discusses, in turn, each of the main research areas, first giving the global scene, then highlighting the UK contribution. A final section summarises and concludes.

\section{HISTORICAL DEVELOPMENT}

Cognitive aspects of the development of financial accounting research as a body of systematic scholarly knowledge are documented in the journal literature. Beattie (2002) traces the historical development of this body of scholarly knowledge from its early origins to the present day, focusing on external and cognitive influences. The 
impetus for the development of accounting as an academic discipline came from events like the 1929 stock market crash in the US and the Royal Mail case in the UK, which prompted a search for a coherent set of principles to underpin financial accounting practice. Paton and Littleton's income determination model filled the theoretical void for many years, and sparked off what has been called the 'golden age' of a priori (i.e. deductive) research in financial accounting, based largely on economic theorising.

Gradually, however, the limitations of the income model became increasingly apparent. It was unable to offer guidance on the appropriate accounting treatment of thorny accounting issues such as pensions and goodwill. It was also gradually realised that no single measure of true income existed, rather the appropriate measure depended upon the decision-context. During the early 1960s, the income determination model gradually gave way, therefore, to a decision-usefulness (or user needs) approach. This was accompanied by an interest in conceptual frameworks to counter the political nature of standard-setting arising from the economic consequences of those standards.

At about the same time, there was a drive in the US towards a more 'scientific' approach to management research. Two distinct areas of empirical research developed - behavioural accounting research (BAR) and market based accounting research (MBAR). Both areas allow the decision-usefulness of information to be investigated. BAR examines the decision processes of individual users and draws on the discipline of psychology for its concepts, methods and models. It includes surveys (conducted via questionnaire and/or interviews), experiments and case studies. MBAR examines the relationship between accounting information and share prices (or returns) (the capital market can be thought of as the aggregate investor), and relies on economics and finance as foundation disciplines. This line of research was sparked off by an interest in the ability of accounting information to predict different variables of interest (such as company failure and share prices) and the development of the Efficient Market Hypothesis (EMH). It was facilitated by Ball and Brown's (1968) development of the share price residual approach to measuring stock market reaction, and the emergence of electronic databases containing share prices (CRSP), financial statement data (Compustat and Datastream) and (more recently) analysts' 
earnings forecasts (IBES). The focus of research was on short-window event studies (termed market reaction or information content studies) and studies of the capital market consequences of accounting standard setting.

During the late 1970s, Watts and Zimmerman (1986) developed a positive theory of accounting which drew on contracting theory and political cost arguments to explain and predict the accounting choices made by companies and their position when lobbying standard-setters. This theory became one of the main theoretical underpinnings of BAR and MBAR. Empirical studies based on positive accounting theory contrasted sharply with the earlier normative theory.

In recent years, the research agenda has been influenced by studies that cast doubt on the validity of the efficient markets hypothesis in its semi-strong form. This has led to renewed interest in experimental financial BAR, interest in the differential impact of recognition versus disclosure, a shift in the focus of earnings management studies, and a major growth in fundamental analysis and equity valuation studies. The research agenda has also been influenced by external events, principally the globalisation of world capital markets, the growth of intangible assets as the major driver of value for many companies and regulatory concerns regarding the 'quality' of financial reporting. In relation to the latter see, for example, the well-known speech by the (now former) Chairman of the Securities and Exchange Commission, Levitt (1998). Accounting practice (and research) is in the process of responding to these events. In the main body of this paper, current research is classified into research areas and recent developments in each area are reviewed.

Finally, a more complete understanding of how and why financial accounting research has developed in the way that it has requires consideration of the social aspects of research activity. Traditionally, the UK and the US have been most influential in the development of both practice and research (Beattie, 2002, p.95). The academic structures and processes in these countries, in particular those relating to academic training and evaluation, are quite different. In the US, professional accounting schools tend not to undertake research, which is concentrated in business schools, whereas in the UK teaching and research are traditionally integrated. ${ }^{4}$ In addition, the skill set of US researchers lends itself to highly quantitative research, drawing upon 
large publicly available databases. UK researchers have traditionally not possessed these skills to the same degree; many more are professionally qualified; and there is a major ongoing interest in the social aspects of accounting. This has resulted in a broader-based research agenda. It may be noted that a similar split in the research cultures and traditions between US and European academics has been found in management research (Collin, Johansson, Svensson \& Ulvenblad, 1996). US researchers favour quantitative (positive) research, whereas European researchers favour qualitative (case study) research.

Lukka \& Kasanen (1996) argue that accounting is a local rather than a global discipline, on the basis that $77 \%$ of academic papers show congruence between the origin of the researcher, the data, and the journal. They identify two competing research élites: a powerful and currently dominant US élite centred around The Accounting Review, the Journal of Accounting Research and the Journal of Accounting and Economics and an emerging, mostly European élite around Accounting, Organizations and Society. A recent world-wide study of faculty perceptions of accounting journals further reinforces this view of two alternative research orientations associated with geographic location. Further, it is shown that Asian researchers hold views similar to North American researchers, while Australian/New Zealanders are more in agreement with Europeans (Ballas \& Theoharakis, 2003).

Closer to home, Carmona, Gutiérrez \& Cámara (1999) offer a profile of European accounting research. They show that UK researchers continue to dominate European contributions to leading journals. However continental European authors are beginning to make an impact

\section{METHODS}

An analysis of the publication outputs reported in the BAR Research Register (Helliar \& Gray, 2000) reveals those journals that UK and Irish researchers publish in most frequently. Beattie and Goodacre (2002) report that, for the whole accounting discipline (i.e. excluding finance), the ten most 'popular' journals (in descending order) are: 
1. Critical Perspectives on Accounting* (including poems)

2. European Accounting Review (EAR)

3. British Accounting Review (BAR)

4. Accounting Education: An International Journal*

5. Journal of Business Finance and Accounting ${ }^{5}$ (JBFA)

6. Accounting and Business Research (ABR)

7. Accounting, Auditing and Accountability Journal (AAAJ)

8. Management Accounting Research*

9. Accounting, Organizations and Society (AOS)

10. Financial Accountability and Management*

Four of these journals (marked with a $*$ ) relate to specialist areas of accounting research outside the boundaries of this review (critical accounting, accounting education, management accounting and not-for-profit organisations) and were not considered further. Although Accounting, Organizations and Society does include a lot of critical accounting articles, it was included because it also includes a few behavioural studies and because it has been identified as the journal central to the European élite (Lukka \& Kasenan, 1996). It is noticable that all of these journals are non-US journals. Abacus (Ab) was also included as it is a well-established general, non-US journal that UK academics publish in with reasonable frequency. These seven journals captured $40 \%$ of academic journal outputs by UK researchers in the period 1998-99 (Beattie \& Goodacre, 2004).

All issues of these seven journals for the four and a half year period from 1998 to mid 2002 were examined to identify articles falling within the boundaries of this review. Articles dealing with international convergence, history, the profession, public sector organisations and stock market efficiency were specifically excluded. The proportion of financial accounting articles varied considerably across the seven journals, as shown in Table 1, and ranged from $15 \%$ for $A O S$ to $46 \%$ for $A B R$. Given that there are no specialist financial accounting journals, in contrast to other major fields in the discipline such as management accounting and auditing, the fact that, on average, only $30 \%$ of the articles in 'general' journals are about financial accounting is cause for concern. 
[Table 1 about here]

Of the 261 financial accounting articles, 115 (44\%) were either exclusively UKauthored or included at least one UK author. Sixteen percent were exclusively USauthored, with only three journals exhibiting a significant proportion of US authorship (JBFA, AOS and $A b$ ). The remaining $40 \%$ of authors, therefore, came from the rest of the world. In the main body of the review that follows, approximately half of the 115 UK articles are specifically cited.

For every financial accounting article identified, the geographical location of the author(s) and of the data (if any) was recorded, along with attributes relating to the content of the research. Classification is of value because it acts as a heuristic device, aiding understanding and interpretation (Rudner, 1966). Research areas are characterised by, arguably, up to three key attributes: the particular topic being addressed; the research methods typically employed; and the particular theory underpinning the analytical and empirical work. Conceptually, one can therefore think of the entire field in terms of a three-dimensional array.

In practice, however, specific research areas tend to be named after a single attribute (for obvious reasons of simplicity) and the review that follows adopts this pragmatic approach, although all three attributes are discussed. Inevitably, therefore, there is some overlap between research areas. The attributes recorded for each article were: the topic area, the principal research method used, and a brief comment about the specific nature of the contribution, including its informing theory (if any). This underpins both an evaluation of the quantum of research effort being put into various research areas as well as a qualitative review of the impact of this effort on the development of scholarly knowledge in the field.

\section{REVIEW}

This main section begins by presenting the quantitative findings from the analysis of recent research published in the field. The review then discusses, in turn, each of the main research areas, first giving the global scene, then highlighting the UK contribution. This discussion is not confined to the journal articles specifically 
reviewed for the purposes of writing this article, not is it confined to academic journal outputs.

\section{Mapping the domain of financial accounting research}

Studies in the field of financial accounting research address one (or more) of the following general questions:

- What should be reported?

- What is reported?

- What explains observed practice?

- What is the association between observed practice and other variables of interest?

\section{Quantitative results}

Before embarking on a discussion of each research area in turn, it is interesting to take note of the quantum of research that has been published in each area over the last five years. Table 2 provides this analysis, although it must be emphasised that these figures are indicative only, as a significant number of papers could be classified into more that one research area. (For example, two experimental failure prediction studies are classed as failure prediction studies rather than financial BAR.)

[Table 2 about here]

It is clear from this table that MBAR research dominates the field (as defined above). Generic disclosure studies and special disclosure topics (CSR and intangibles) account for approximately $23 \%$. Other topics each take less that $7 \%$ of the total. The pattern for studies involving UK authorship is broadly similar.

It is also interesting to note the country from which data is sourced by the 115 studies involving UK authors. ${ }^{6}$ In 72 cases, exclusively UK data was presented, with a further 5 studies involving several countries including the UK. In 22 cases, there was no real-life data used. In the remaining 16 studies, data was sourced from 11 separate countries, as follows: the US ( 3 cases), Spain ( 3 cases), Malaysia ( 2 cases), and 1 case each for Australia, Belgium, Czechoslovakia, France, Germany, India, Japan, and new Zealand. 
An issue closely related to the country from which data is sourced is the home country of non-UK co-authors. Twenty-two studies involved co-authorships by at least one UK researcher and at least one non-UK researcher. ${ }^{7}$ The wide geographic spread of these co-authorships suggests that many arise from relationships that began when nonUK students came to the UK to undertake a research degree. Now back in their home country as academics, they are publishing with their former supervisor. Others coauthorships, especially continental European links, may have been facilitated by the activities of the European Accounting Association.

Finally, the incidence of use of different research methods is shown in Table 3. Half of all studies use archival methods. Apart from the use of reasoned argument, no other method is used in more than $10 \%$ of financial accounting studies.

\section{[Table 3 about here]}

\section{Normative (a priori) theorising}

It seems clear that academics have largely disengaged from traditional normative theorising in relation to financial statements, by which is meant the use of reasoned but informal, natural language argument to support the case for or against particular accounting treatments. This type of research, frequently grounded in economic income theory and adopting a measurement perspective, debates fundamental accounting problems to do with recognition and measurement, often in the context of specific accounting issues of the day (e.g. the treatment of convertible debt, employee share schemes). A recent UK example is Forker (2000). Bromwich (2001) provides a valuable discussion of the theoretical bases of the ASB's Statement of Principles (1999). He argues that, while an economic perspective is adopted, measurement issues require further development and the economic perspective is inevitably moderated by practical considerations relating, inter alia to realization, matching and accruals.

There are likely to be several reasons for the decline in the 'popularity' of such papers, but the changing knowledge base and skill set of the 'average' academic must be first among these. Specifically, there has been a significant reduction in the 
number of academics with a professional accounting qualification (this decline is specifically noted in Otley's (2002) review of the 2001 RAE 2001).

Most 'theoretical' papers are now of the formal analytical modelling variety. While the latter approach has rigour, the models are inevitably based on a set of simplifying assumptions that seldom captures the complexities of the real world. Undoubtedly this offers significant advantages in sharpening our understanding of key relationships. The downside is that such papers often have no immediate policy relevance. This type of research, however, is not widely undertaken due to the theoretical difficulties presented by the accounting setting of incomplete and imperfect markets. ${ }^{8}$ The application of information economics models with the explicit recognition of decision-making under uncertainty, underpins the information approach to accounting theory. ${ }^{9}$ UK researchers have made important contributions to consolidating this approach in books (Strong \& Walker, 1987; Bromwich, 1992). There remain considerable research challenges to the analytical researcher, however, and these are well set out in the recent book by two non-UK researchers, Christensen \& Demski (2003).

\section{Financial BAR}

\section{$\underline{\text { Survey and case study }}$}

UK research in this area is predominantly conducted via interviews, questionnaires and participant observation. Different interested parties are studied, principally preparers and users. The focus of effort has been on professional (i.e. expert) users such as fund managers and investment analysts. Analysts represent a crucial group due to their role as information intermediaries in the capital market. Papers by Barker $(1998,1999,2000)$ use this mix of methods to explore the use made of accounting information. Another (non-BAR) approach to investigating the use made of accounting information has been to infer use from a content analysis of analysts' reports (e.g. Breton \& Taffler, 2001).

Other studies use exclusively a questionnaire approach to monitor users' information sources (Bartlett \& Chandler, 1997); elicit users' attitudes to specific disclosures (Solomon, Solomon, Norton \& Joseph, 2000); establish users' use of accounting information (Miles \& Nobes, 1998); and elicit users' declared information needs 
across a comprehensive range of actual and potential business reporting information items (Beattie \& Pratt, 2002). Yet other studies use exclusively the interview method and UK studies of this type relating to corporate social reporting (CSR) and enforcement mechanisms are discussed below.

\section{Experimental}

Experimental research in the field of financial accounting has traditionally not been very popular (relative to the fields of management accounting and auditing). This is largely because it was argued that, in an efficient market, the individual was irrelevant. However, given recent evidence casting doubt on market efficiency, interest in such research has grown. In addition, it is increasingly being recognised that the complexity of natural settings makes it difficult for archival studies to disentangle the influence of particular variables of interest.

Recent financial BAR has been more rigorously theorised and carefully designed, allowing causal inferences to be made. Libby, Bloomfield \& Nelson (2002) provide a good review of the recent research in the area, although the emphasis is on the US contribution. It remains, however, an area where the vast majority of research is undertaken by US academics (who are well-trained in the relevant research methods). Of the 12 financial BAR studies in Table 2, six were experimental studies, and all but one were from the US. These studies examine the search, selection, encoding and retrieval of information by different classes of decision-maker (e.g. well-informed vs. less-informed).

Financial BAR studies represent, in the main, a subset of studies relating to the general issue of disclosure (discussed below).

\section{Market based accounting research (MBAR)}

This is a vast area of research that is moving forward very fast. The decline in the costs of doing such research due to the low-cost availability of relevant databases may have contributed to the explosive growth in the area (Kothari, 2001). In addition, the nature of US $\mathrm{PhD}$ training encourages projects that are capable of completion over a relatively short time period, and the ready availability of data for market based studies therefore make them attractive. Recent reviews of the broad sweep of MBAR can be 
found in Kothari (2001), Beaver (2002) and Dumontier \& Raffournier (2002). The former two papers tend to emphasis the US literature, while the latter paper is specifically concerned with the European literature. ${ }^{10}$

The residual income valuation approach has been around for some time and relies on economic income concepts, which are net present value based. ${ }^{11,12}$ It seeks to relate accounting measures to economic present value concepts. EVA®) (Economic Value Added) is a commercial value-based performance metric, advocated by Stern Stewart \& Co. and a variant of residual income. In a series of articles, Grinyer has made an important UK contribution to this literature (e.g. Grinyer, 1985). Grinyer has proposed a special case of residual income (which he calls Earned Economic Income (EEI)) as a single-period residual income measure to be used as a performance indicator that is consistent with the NPV model. UK researchers have also contributed valuable discussions of the residual income valuation models. Bromwich \& Walker (1998) evaluate the strengths and weaknesses of management incentive systems based on the residual income concept, while O'Hanlon \& Peasnell (1998) assess its role as an overall measure of corporate performance, highlighting its potential shortcomings as a single-period performance indicator.

Renewed impetus for MBAR came from the mounting evidence of apparent market inefficiency. It also came from the development of the Feltham-Ohlson model (Ohlson (1995), Feltham \& Ohlson (1995) and related papers). ${ }^{13}$ This analytical model has been described as one of 'the most important research developments in the last ten years' (Beaver, 2002, p.457). It develops the residual income valuation model to show how the clean surplus relation ${ }^{14}$ can be used to generate predictions about the relation between market prices, book value and earnings. ${ }^{15}$ Thus, accounting book values and accounting profits (defined in terms of residual income) are set within traditional capital market valuation models under relatively few assumptions.

Its contribution is to provide a theoretical framework for MBAR that integrates both measurement and information perspectives for accounting information (i.e. it integrates the early normative approach with modern finance theory). The model is parsimonious, and does not incorporate information asymmetry - a key feature of many issues of interest to accounting researchers. Subsequent modelling has, 
however, enriched the basic model, thereby providing a role for many important features of the accounting system, such as conservatism, and different decompositions of earnings. A few UK researchers have made notable contributions to this modelling literature. Cooke \& Tippett (2000) examine the structure of the double entry bookkeeping system and demonstrate the conditions in which non-linear relationships exist between bookkeeping summary measures and the market value of equity. Ashton, Cooke \& Tippett (2003) also focus on non-linearities. Using a generalization of the linear information dynamics that underpins the Ohlson (1995) model, they present an aggregation theorem which shows that the recursion value of equity is functionally proportional to its adaptation value. Hence the market value of equity (the sum of recursion value and adaptation value) will be a highly convex function of its adaptation value. Supporting UK evidence is presented. The implication of this is that empirical evidence based on the linear approach to residual income valuation is very difficult to interpret.

\section{$\underline{\text { Fundamental analysis and valuation }}$}

Evidence of market inefficiency and the development of the Feltham-Ohlson model have prompted a new wave of research on the value of fundamental analysis (the term 'value relevance research' came into common usage in the 1990s). Most studies are based on the combined book value and earnings approach of the Feltham-Ohlson model. These are long-horizon studies that examine the association (via regression analysis) between accounting signals and market data (stock prices and returns). The significance of regression coefficients and $\mathrm{R}^{2}$ statistics are examined to evaluate value relevance. A signal is deemed value relevant if it is significantly associated with equity market value (i.e. if it is priced).

The focus is on the role of accounting numbers for valuation purposes; other important purposes of accounting numbers, such as contracting purposes, lie outside the remit of this research area. In some cases it is of interest to compare the valuation multiples of similar accounting numbers (the various components of earnings). Value relevance studies typically incorporate a rich accounting context relating to the accounting institutions and the specific features of the accounting standards being examined. Timeliness is often not an issue of concern. 
Research has examined the value relevance of many different accounting numbers, some of which may appear only in footnote disclosures and some of which may be voluntary. Examples are earnings, earnings components, management earnings forecasts, alternative non-GAAP definitions of earnings such as value added and EVA, unrecorded pension assets and liabilities, the fair value of financial instruments, unbooked environmental liabilities, non-financial intangible assets (such as capitalised software and brands) and expenditures on research and development and advertising.

Recent reviews of this area focusing on the US literature can be found in Holthausen \& Watts (2001) and Barth, Beaver \& Landsman (2001). In general, non-US studies have replicated the thrust of US studies. However studies undertaken in different settings are essential as they permit independent tests of the value of fundamental analysis. Significant national differences have been found to exist and are attributed to the degree of accounting conservatism inherent in different countries' financial reporting standards and to the specifics of the institutional setting. ${ }^{16}$ It then becomes interesting to specifically compare the value relevance of accounting signals across different settings.

UK researchers have made a very significant contribution to this area of MBAR, not only by undertaking studies in the UK setting (sometimes with non-UK researchers) but also in other national settings (often working with researchers from that country). Recent studies using UK data have shown, inter alia, that:

- simple residual income measures have a stronger link with market value relative to earnings, supporting the use of residual income for planning and control purposes (Stark \& Thomas, 1998);

- there is little evidence that accounting flows excluded from ordinary profit (other than extraordinary items) are value-relevant, allaying fears that dirty surplus accounting practices have promoted undesirable creative accounting practices (O’Hanlon \& Pope, 1999);

- the properties of three key accounting ratios (market-to book ratio; accounting rate of return; and price-earnings ratio) and the associations between them provide evidence that returns tend to lead earnings (O’Hanlon, 1998); 
- 'headline' EPS has incremental explanatory value while FRS3 EPS does not (Lin \& Walker, 2000);

- the disaggregation of cashflow under FRS1 has information content (Garrod \& Hadi, 1998);

- foreign earnings and assets are valued more highly than their domestic equivalent (Garrod \& Rees, 1998);

- the partial (but not full) provision method of accounting for deferred tax is valued (Citron, 2001);

- cashflow information has value relevance in the long-run and is influenced by contextual factors (Charitou \& Clubb, 1999; Charitou, Clubb \& Andreou, 2001); ${ }^{17}$ and

- MD\&A narratives (especially forward-looking information) have information content (Schleicher \& Walker, 1999).

Even within a single national setting, the specific dynamics of the relation between market data and accounting signals will vary, depending on the stage in the economic cycle, industry, and specific company circumstances (Al-Debie \& Walker, 1999) and on the richness of the information environment.

Because earnings incorporate value relevant events with a lag (due to the rules for accounting recognition), the association between contemporaneous earnings and market data is particularly low. In a significant paper, Pope \& Walker (1999) investigate, analytically and empirically, the differential speeds of recognition of good and bad news. Their findings indicate that, while good news exhibits a recognition lag of one year, bad news is anticipated by up to two years. ${ }^{18}$ Adopting the same approach, Giner \& Rees (2001) find that the contemporaneous association between earnings and returns is stronger for bad news (and similar across France, Germany and the UK).

\section{Market reaction studies}

Short-horizon studies of the market reaction to accounting disclosures continue to be undertaken. Information content is inferred from changes in the level or volatility of returns or changes in trading volume. Studies address the information content of 
annual earnings, the components of earnings, interim earnings, other accounting signals and, increasingly, financial and non-financial disclosures made outside the financial statements.

Replication of earlier US studies in other capital market settings are of interest because of differences in both the formal and informal financial reporting environment, the pattern of share ownership and the economic background. In general, significant associations have been found across all settings. The focus has been on mandatory disclosures, especially earnings announcements. For example, Pellicer \& Rees (1999) study the Spanish market,. Market reaction has been found to differ across firms and studies have begun to explore the reasons for these differences.

An offshoot of these valuation studies has been consideration of the market value effects of creative accounting. The main objective is to establish whether discretionary accruals are motivated by opportunism or signalling (with the latter being consistent with a positive association between discretionary accruals and market data). This line of research provides a link to the earnings management studies discussed below.

Another offshoot has been the use of valuation models to estimate the equity risk premium. O'Hanlon \& Steele (2000) present UK evidence. These measures can then be used as inputs to other studies.

\section{$\underline{\text { Analysts' forecasts }}$}

Research on analysts' forecasts is undertaken because of their critical role as information intermediaries and hence facilitators of market efficiency. Analyst forecasts can also be useful inputs into market based accounting studies, since they capture a rich information set. Early studies focused on accuracy, bias and efficiency, while more recent studies explore analysts' incentives and seek to identify the information set (both accounting and non-financial signals) upon which forecasts are based.

US research shows that analysts' forecasts are optimistic (with the degree of bias related to underwriter affiliation) and that they outperform statistical models based on 
the time series of earnings. Analyst coverage is positively related to the importance of institutional investors and the significance of intangible assets.

The optimism bias has also been documented in the UK (e.g. Capstaff, Paudyal \& Rees, 1995). Subsequent studies have sought to identify the factors associated with accuracy and bias. Capstaff et al. (1999) find that forecast accuracy varies across brokers, while Hodgkinson (2001) reports that the closeness of the working relationship between analyst and firm does not improve forecast accuracy but stimulates optimistic forecasts, and Hussain (2002) looks at the impact of brokers' institutional characteristics. Capstaff et al. (2001) compare accuracy and bias across nine European countries, finding an endemic optimistic bias but also significant differences that future research should seek to explain.

Hussain (1998) documents and examines the nature of the superiority of analysts' forecasts over lead indicator models, while Hussain (2000) explores the factors associated with analyst following. Research has also shown that the additional information about earnings components provided by FRS3 helps UK analysts distinguish permanent from transitory earnings (Lin, 2002) and increases the accuracy of analysts' forecasts (Acker, Horton \& Tonks, 2002).

In concluding this discussion of MBAR, it can be noted that there are clear limits to what can be learned from this line of enquiry. In particular, MBAR does not address the process by which the market anticipates future earnings reports (for example, by managers making private disclosures to analysts and fund managers). Nor does it address the use of accounting information for stewardship purposes or contract enforcement purposes. The next sub-section examines research that takes the issue of disclosure as its central theme.

\section{Disclosure}

The amount of research focusing on the central theme of disclosure has also been growing rapidly in recent years. This literature addresses both mandatory (i.e. nondiscretionary) and voluntary (i.e. discretionary) disclosures, both of which may be disclosed formally or informally. The emphasis, however, has recently been on voluntary, public disclosures. Although it is becoming commonplace to refer to 'the 
disclosure literature', it comprises several disparate strands. ${ }^{19}$ One strand is analytical, seeking to model the disclosure decision, while the empirical literature covers descriptions of actual practice, studies of the disclosure decision and the capital market consequences of those decisions. ${ }^{20}$ This latter strand constitutes a link to the MBAR research area and studies of this type have been discussed above. The study of capital market consequences includes studies into the role of information intermediaries, such as financial analysts.

This literature has burgeoned for two main reasons. First, it represents a natural development of existing research areas that adopt a political cost perspective and a capital market perspective. Positive accounting theorists, who rely on economics for their informing theories, have sought to move on from explaining accounting policy choices (i.e. discretionary choices within mandated disclosures) to explaining voluntary disclosure choices. In addition, market based accounting researchers have increasingly explored the capital market consequences of a range of accounting signals other than earnings.

Second, growth in this area can be partly attributed to the practical matter of changes in the business environment (frequently labelled as the 'New Economy' or ' $\mathrm{k}$ economy'). These changes have led many to argue that the traditional accounting model, with its strict recognition test and emphasis on historical, financial information, no longer satisfies users' needs. Critics point to the large gap between book values and market values and the need for businesses to be flexible if they are to adapt and survive. The call is for a comprehensive model of business reporting that includes forward-looking information relating to strategy and risk, non-financial performance measures and soft, narrative information relating to intangible assets and the value creation process, to complement the financial information on outcomes (AICPA, 1994; FASB, 2001; Power, 2001). This has fuelled research into voluntary disclosure, including accounting narratives.

There is a strong, predominantly US, literature that offers increasingly sophisticated economic models of the discretionary disclosure decision. These are rigorous mathematical models based upon a set of simplifying assumptions, designed to highlight one particular aspect of the disclosure decision. In the early literature, two 
main disclosure theories emerged, which focused on the incentives and disincentives for voluntary disclosure. Diamond's (1985) information cost savings theory showed analytically that if a company commits to a policy of disclosing relevant information, it will preempt investors' private information search activity, providing an improvement in welfare by reducing overall information production costs. In other words, the additional information production costs of preparers are outweighed by the reduction in information search costs by users. Verrecchia's (1983) proprietary cost theory showed that the incentive to disclose information is a decreasing function of the potential proprietary costs attached to disclosure and an increasing function of the favourableness of the news.

Walker (1997b, ch.3) provides a useful review of these and subsequent economic theories of financial information supply based on game theory and information economics. The assumptions of these models relate to (i) the manager's objective, (ii) the users of disclosed information (investors only or investors and third parties) and (iii) whether or not misrepresentation by management is possible. Walker notes that while these models cannot capture the complexity of real-life disclosure decisions, they do isolate key influences: the objectives of corporate executives; financing requirements of companies; managerial incentives; and how third parties use corporate disclosures.

Healy \& Palepu (2001), and the discussion thereof by Core (2001), jointly provide a good review of the (largely US) economics-based empirical disclosure literature. While Healy \& Palepu adopt a broad theoretical framework based on Akerlof's (1970) adverse selection problem, Core (2001) argues the need for a more specific theoretical framework to explain cross-sectional differences in firm's disclosure policies. In particular, he argues for the need to recognise that disclosure policies are endogenously determined by the same forces that shape firms' governance structures and management incentives.

Disclosure 'quality' is defined as 'the firm's ongoing ex ante commitment to provide disclosure' (Core, 2001, p.448). Core (2001, p.452) argues for the need to create better disclosure quality metrics if research into disclosure is to advance significantly. Subjective analyst disclosure rankings are not always available and researcher-created 
disclosure indices (such as that created by Botosan, 1997) are partial. Researchers in the UK are making a contribution in this regard. On the basis of a holistic content analysis of the accounting narratives, Beattie, McInnes \& Fearnley (2002) argue that quality can be assessed by looking at the size-adjusted amount of disclosure, the spread across topics and the type attributes of disclosures. Hussainey, Schleicher \& Walker (2003) have experimented with computer-based searches looking for disclosures with a forward-looking type attribute.

A particular focus of recent research relates to the link between disclosure quality and the firm's cost of capital. Both variables suffer from measurement problems. The cost of equity capital is measured using the Feltham/Ohlson accounting based equity valuation model discussed above.

\section{A grounded theory of disclosure}

While some UK researchers adopt the informing theories of economics, following the US tradition, others take a broader perspective on disclosure. Some eschew the analytical modelling approach, instead seeking to develop, inductively, a grounded theory of the disclosure process. In a seminal article, the Canadian researchers Gibbins, Richardson \& Waterhouse (1990) developed a comprehensive model of corporate disclosure strategy.

This model has since been tested and extended by UK researchers, in particular by Barker (1998) and Holland (1998a; b). Barker (1998) uses predominantly interviews with finance directors, analysts and fund managers to develop a grounded theory of the market for information. He suggests that fund managers place greater importance on raw data received directly from companies than processed data received via analysts. The key role of analysts lies instead in the provision of benchmarks for consensus valuation.

In a major study, Holland undertakes interviews during 1995/96 with the senior executives (chairmen, CEOs, finance directors and investor relations directors) in 33 large listed UK companies. Holland (1998a) describes the private disclosure process between companies and institutional shareholders and the way in which this interacts with public voluntary disclosure activity. The role of financial reports in the larger 
corporate disclosure process is also identified. Holland (1998b) further reports on the drivers of private corporate voluntary disclosure. He argues that the focus of extant research (public disclosures, the behaviour of informed traders and share price impact) leads to a partial theory and calls for the development of a combined theory that links private and public disclosure in a dynamic manner.

The remainder of this subsection considers two disclosure topics that have attracted particular interest in recent years: CSR and intangibles.

\section{Corporate social reporting (CSR)}

Another strong strand of research in the UK (and Australia) relates to corporate social reporting. This term is used to refer to social, environmental and ethical reporting (principally self-reporting by organisations). Reviewing the area in 1995, Gray, Kouhy \& Lavers (1995) noted the lack of overall coherence of the literature, attributable in part to the 'lack of any agreed theoretical perspective to drive systematic research' (p.47). Practices are documented, attitudes are elicited, explanations of disclosure practices are sought, the consequences of disclosure are analysed, and the role of CSR in organisation-society dialogue is investigated.

Most of this literature draws upon social and political theories to provide a theoretical framework. $^{21}$ In particular, the overlapping perspectives of stakeholder theory and legitimacy theory, set within a political economy framework, are argued to offer most promise. A more recent review by Gray (2002) notes that the social accounting literature is increasingly informed by the alternative/critical project.

The UK contribution of recent years has maintained a fairly eclectic mix of 'conventional' and 'critical' studies (though critical studies are, strictly, outside the boundaries of the present review). Quantitative content analysis combined with archival data, qualitative interviews, and reasoned argument are the research methods most commonly adopted. In a study typical of the quantitative approach, Adams, Hill \& Roberts (1998) seek to identify corporate characteristics that influence types of social disclosure across six European countries. 
Interview based studies include: Friedman \& Miles (2001) who explore the links between CSR and socially responsible investment through interviews with experts in the SRI field; Woodward, Edwards \& Birkin (2001) who elicit the attitudes of executives in large UK companies towards their perceived social responsibility and seek to analyse these using a blend of theoretical perspectives; and Adams (2002) who seeks to develop explanatory theory by focusing on the influence of internal contextual factors, based on interviews with company officers.

In a study relying on reasoned argument, Bailey, Harte \& Sugden (2000) argue that transnational companies need further regulation in respect of their social and environmental impact.

The diversity of approach to the study of CSR can further be illustrated by noting that recent non-UK (and non-US) studies have commonly employed, in addition to the above methods, the case study approach, the experimental approach and questionnaires.

\section{$\underline{\text { Intangibles, including intellectual capital }}$}

This topic has come to the fore due to the growing gap between the book value and market value of companies. This arises in large part because intangible assets do not fulfill the accepted recognition criteria. As a consequence, there is considerable interest in ways of reporting on such assets outside the audited financial statements. Several top journals have carried special issues on this topic in the last two years.

While the US literature has examined the value relevance of specific items of disclosure related to intangibles, the non-US literature has focused on the reporting of intangibles as a whole, with specific reference to intellectual capital. The preferred method used in empirical analysis has been the case study, with an element of normative theorising based on reasoned argument. UK studies of this nature are Holland (2001), who examines the link between intangibles reporting and corporate governance and Roslender \& Fincham (2001) who argue for a more critical approach to the reporting of intellectual capital. It should be noted, however, that it is Scandinavian countries that have been at the forefront of reporting practice and research in this area. 


\section{Other business reporting issues: special formats and media}

While the focus of most disclosure research is, not surprisingly, on accounting numbers, increasing attention is being given to the business reporting package within which the accounting numbers are embedded. This package contains a variety of other formats (narratives, graphs and pictures). The multiples formats found in annual reports have been explored from a variety of perspectives.

The North American literature has largely confined itself to the information value of narrative disclosures found in the management discussion and analysis (MD\&A) (e.g. Barron, Kile \& O’Keefe, 1999; Clarkson, Kao \& Richardson, 1999). Schleicher \& Walker (1999) undertake a MBAR study in the UK. The general approach is to convert natural language text data into a number via the construction of a disclosure index. This number is then used in large-scale statistical analyses, in the quantitative tradition of US research.

The non-US literature has instead tended to focus on the neutrality of the text, graphs and imagery found in annual reports and its constructive potential. Several papers address methodological issues concerning the measurement of underlying textual, graphical and visual constructs. Other papers document corporate practice and propose theoretical frameworks to explain the characteristics of the disclosures found. These tend to be general frameworks that draw on fields other than economics, especially psychology, linguistics and literary analyses. In particular, the ideas of impression management (Beattie \& Jones, 2000) and attribution theory (Aerts, 2001) have been explored.

In the area of narratives, an interesting methodological paper by Sydserff \& Weetman (1999) suggests the use of linguistic analysis. They propose a texture index, which captures a rich and varied set of text characteristics. Previous research has focused on readability formulas adapted from the education discipline to capture this single dimension of text (e.g. Clatworthy \& Jones, 2001, who explore possible determinants of readability variability). Researchers are now beginning to apply literary analysis to the annual report text (Davison, 2001). 
In the area of graphs, the focus has been on cross-sectional studies documenting the use of graphs and potential biases due to selective use, measurement distortion or presentational enhancements (e.g. Beattie \& Jones, 1999). A series of papers by Beattie \& Jones has been instrumental in developing this niche disclosure topic. Most recently, attention has turned to developing more powerful time-series tests of selectivity (Beattie \& Jones, 2000) and experimental work that explores the impact of different graph construction and design features on users' perception of company performance (Beattie \& Jones, 2001; 2003).

Finally, a set of studies in AOS in 1996 (surprisingly, mainly US-authored) was key to the development of interest in the visual imagery found in annual reports, which continues (e.g. Preston \& Young, 2000; and Davison, 2001).

The development of reporting on the Internet has inevitably resulted initially in descriptive studies documenting corporate practices with regard to this new medium of dissemination. The first wave of research effort concentrated on the content analysis of websites (for examples, see the special issue of $E A R$ in 1999) and the company-specific characteristics associated with observed practices. Subsequent empirical research is just beginning to explore related issues, such as the reasons for observed practice via interviews and case studies (e.g. Craven \& Marston, 1999) and users' preferences with regards to the new medium (Beattie \& Pratt, 2003). In a nonempirical paper, Jensen and Xiao (2001) argue that web-reporting together with XBRL technology makes possible customization around a standard report, enabling users to extract tailor-made information sets.

\section{Earnings management}

Earnings management studies consider three types of management incentive: contracting, political cost ${ }^{22}$ and (more recently) capital market arguments. The latter perspective looks at attempts to influence short-term share price performance or meet analysts' forecasts. During the 1990s, the discretionary accruals models of Jones (1991) and the modified Jones model (Dechow, Sloan \& Sweeney, 1995) came into prominence. However, McNichols (2000) has recently argued that the earnings management measures based on these models are not sufficiently powerful or reliable to assess earnings management behaviour in many contexts. While many studies still 
examine aggregate discretionary accruals, interest is turning towards specific accruals (such as provisions for bad debts and deferred tax) and distribution-based tests.

Recent UK research in this area has focused on examining the properties of alternative discretionary accruals models. Young (1999) evaluates the measurement error on five models, highlighting the limitations of existing models, while Peasnell, Pope \& Young (2000a) explore the power of three models (the Jones model, the modifiedJones model and a new 'margin model') in cross-sectional specification. They find that the models' ability to detect earnings management varies across specific accruals.

Other UK studies have begun to explore the factors that limit earnings management behaviour, such as corporate governance structures (Peasnell, Pope \& Young, 2000b). There is also a strand of research that adopts a less quantitative approach to the study of earnings management. For example, Shah (1998) uses a case study approach that includes interview, documentary and financial statement evidence to investigate the accounting treatment of premium put convertibles.

\section{Accounting choice}

Accounting choice studies became very popular following the introduction of positive accounting theory to the accounting literature (Watts \& Zimmerman, 1986 offer a good review of early studies). Contracting and political cost arguments continue to be the focus of studies, although signalling arguments are also now found. Recent UK studies have examined both specific choices (e.g. Lin \& Peasnell (2000) study the asset revaluation decision) and the set of choices (e.g. Young (1998) examines alternative explanations for discretionary accruals, while Pierce-Brown \& Steele (1999) look at the combined effect of twelve key policies).

\section{Economic consequences}

This is a group of studies that examines the causal effects of specific accounting treatments. In particular, the impact on accounting ratios, preparers' decisions and users' decisions (at the individual and aggregate level) are examined using a variety of methods (analytical modelling, archival, market-based, survey and experimental). The underlying theoretical framework (if one is specified) tends to adopt a contracting or capital markets perspective. The specific accounting treatments studied tend to 
reflect the concerns of the day. Recent UK studies have examined accounting for goodwill, leases and bid transaction costs. Gregory (2000) finds that goodwill writeoff considerations influence the form of payment used in the acquisition. Beattie, Edwards \& Goodacre (1998) show that the capitalization of operating leases would have a significant impact on the magnitude of key accounting ratios and on the rankings of companies based on these ratios. Meeks \& Meeks (2001) demonstrate analytically that the accounting treatment of bid transaction costs affects performance measures used in salary contracts and the markets for executives and for corporate control. As a consequence, the managers of bidding companies have an artificial incentive to inflate their bid price or make a bid that is not in shareholders' best interests.

This is an area of research with high policy-relevance and the insights gained from such studies tend to be specific to the accounting issue under investigation and often also to the country where the regulations surrounding the accounting treatments being studied emanate from.

\section{Failure prediction}

This is a relatively small, longstanding niche area of research which emerged several decades ago alongside MBAR when the research focus was on the predictive ability of accounting information. A major focus is the development (using statistical techniques such as discriminant analysis or logit) of a z-score, which combines the predictive properties of several accounting ratios. In the UK, Taffler has made a notable contribution (e.g. Taffler, 1983). Researchers have also applied neural network models ( a simulation approach used in pattern recognition tasks) to failure prediction. In a review, Trigueiros \& Taffler (1996) conclude that neural networks can easily result in overfitting and are only likely to dominate conventional statistical methods when strong non-linearities and interactions between independent variables are present.

Because corporate failure prediction (and its resolution) remain events of considerable interest, research continues. The performance of different types of model is compared and experimental studies examine the performance of human decision-makers. Neophytou \& Mar Molinero (2004) propose the use of multidimensional scaling (a 
visual statistical technique) Other recent studies seek to identify new accounting or non-accounting variables to include in the model. Charitou, Neophytou \& Charalambous (2004) find that operating cash flow has incremental explanatory power using a recent UK sample. Smith \& Taffler (2000) make an interesting contribution by exploring the link between narrative disclosures and firm failure.

\section{(....and finally) Standard-setting}

This research area examines aspects of the regulatory context within which companies make their disclosure decisions. It covers conceptual framework studies and lobbying studies (which concern the standard-setting process) as well as studies of compliance with regulations and enforcement mechanisms. Conceptual framework studies tend to examine specific accounting topics (e.g. employee stock options) in terms of the framework, typically concluding that the framework is too abstract to offer clear guidance. A more critical UK contribution is offered by Page \& Spira (1999), who examine the role of metaphor in conceptual framework debates and suggest that conceptual frameworks serve multiple purposes, such as marketing standards to preparers and users.

Lobbying studies draw upon various theoretical perspectives to inform the analysis (e.g. positive accounting theory, sociological theories). These studies seek to explain the interests, position and power of various groups, either with reference to proposals on specific accounting issues or across a broad set of issues. The most comment research method used is the content analysis of letters of comment, sometimes supplemented by documentary evidence of the actions taken by various groups. Recent UK studies have examined lobbying in relation to the consultation process on goodwill standard FRS10 (Gore, Taib \& Taylor, 2000) and FRS3 (Weetman, 2001). Weetman concludes that the formal consultation process leading to FRS3, the first standard produced by the Accounting Standards Board, served the purpose of a symbolic ritual to establish the acceptance and acceptability of the new regulatory agency.

Non-US research into compliance and enforcement has emerged principally from the UK and has centred on issues to do with the Financial Reporting Review Panel (FRRP), the uniquely UK oversight body. Peasnell, Pope \& Young (2001) follow the 
line of US research into SEC Enforcement Actions and seek to distinguish the performance and governance characteristics of firms subjects to adverse rulings by the FRRP. In contrast, Hines, McBride, Fearnley \& Brandt (2001) and Fearnley, Hines, McBride \& Brandt (2002) use interview methods to explore the role and effect of the FRRP. Interviews with key members of the FRRP and with company directors and audit firm partners having direct experience of FRRP are undertaken. It is concluded that, while there is some evidence that the FRRP has engaged in myth building, it has provided incentives for preparers and auditors to improve accounting compliance and, therefore, can be deemed an effective regulator.

It is worthwhile commenting here on the relevance of the value relevance literature for financial accounting standard-setting. Opposing views are presented in the recent US review papers by Holthausen \& Watts (2001) and Barth et al. (2001). The former argue that the 'mere associations' that emerge from such studies have limited implications for standard-setting, while the latter argue that 'fruitful insights' emerge, especially regarding the effects of accounting conservatism.

The earnings management literature has been judged to thus far have provided only 'modest insights' for standard-setters (Healy \& Wahlen, 1999, p.380). It is argued that standard-setters will be unsurprised by the finding from aggregate accruals models that earnings management occurs. What is now required is studies that identify which accounting standards are used, what the dominant underlying motivation is and what factors constrain such behaviour?

\section{SUMMARY AND CONCLUSIONS}

Given the breadth and depth of the field that this review attempts to cover, the discussion clearly has not been comprehensive. The focus has been on setting out the UK contribution, given that extant reviews of individual research areas tend to be written from a US perspective.

This paper has discussed some of the principal external, internal cognitive and internal social factors that have influenced recent developments in the field of financial accounting research globally. A systematic overview of recent research in the field is 
presented, based upon an analysis of 261 articles published between 1998 and 2002 in seven general, non-US journals. These are the journals that UK academics publish in most frequently and 115 of the articles are UK-authored.

The field is split into (inevitably overlapping) research areas based on an examination of the attributes of each article (topic area, research methods and informing theory). It is found that the research areas of MBAR and disclosure dominate. Since most (though by no means all) studies in these areas are archival studies, it is not surprising to find that archival methods are used in half of all studies. It was also noted that it is not unusual for UK authors to co-author studies with researchers from other countries (especially continental Europe), often using data from these countries.

Examination of the content of the 115 UK papers showed that the UK is characterised by extremely diverse research genres - from the highly quantitative, economicsbased, positive US tradition, through to the qualitative, relativist/critical tradition, with all shades in between. It is also clear that there has been a distinctive UK contribution made in several research areas. However, given the relatively small amount of financial accounting researchers undertaken in the UK, this distinctive contribution can often be traced to just a few individual researchers. ${ }^{23}$

In the area of MBAR, certain areas of disclosure research and earnings management, essential replication studies are being undertaken in settings other than the US. Replication studies apply established theoretical frameworks and research methods to new data sets. It is worth stating explicitly that such studies have the potential to make a significant contribution to knowledge. It is important, however, that the data set used is selected for good reasons. Each data set is embedded in a particular financial reporting environment - cultural, institutional, economic and regulatory. Researchers need to select the environment in a purposeful way, so that the possible reasons for observed differences in findings can be attributed and the variables of key interest are focused upon. This work is critical to improving our understanding of the impact of institutional factors on the relationship between accounting signals and the market and on disclosure decisions. 
Another good reason for undertaking replication studies is that more powerful tests of disclosure theories are possible in settings where greater variation is possible due to less stringent regulation. Given that the US market is heavily regulated, other countries are being studied by non-US researchers (and a few US researchers). It is likely that significant insights will emerge from attempts to understand the reasons for country differences in market effects, disclosure decisions, earnings management behaviour and analysts' behaviour. It is, of course, first necessary to document these differences.

One of the most active research fronts exists in the area of voluntary disclosure. Core (2001, p.442) rightly argues that 'the voluntary disclosure literature appears to offer the greatest opportunity for large increases in our understanding of the role of accounting information in firm valuation and corporate finance'. It is likely that future research will increasingly seek to address endogeneity and measurement problems. In particular, there is a critical need to develop disclosure metrics, and UK researchers are making a significant contribution in this regard. The development of a grounded theory relating to disclosure is another specific areas where a distinctive UK contribution is apparent. This body of work seeks to develop a comprehensive model of disclosure that encompasses both public and private disclosure. Given the benefits of using multiple methods, it seems possible that insights into the dynamics of the disclosure process will prove valuable in improving the design of large-sample studies.

In the areas of both MBAR and disclosure, there is significant potential for crosscountry comparisons within the EU when listed companies in all countries will be attempting to adopt international accounting standards (from 2005 onwards). In the run-up to 2005, there will be new information in the financial accounts, the degree of novelty varying across countries.

Other areas where a distinctive UK contribution is apparent are in the topic areas of CSR and non-numerical formats in the business reporting package (i.e. narratives, and graphs) as well as in the use of qualitative and case-based methods. 
Given the relatively low number of UK researchers, and the epistemic diversity evident in UK research, it becomes difficult to generate a critical mass of research that is widely recognised as moving the research front forward. Nevertheless, in recent years, 'hot spots' in the field of mainstream financial reporting seem to have existed at a few institutions.

In addition to making a direct contribution to the literature, UK researchers appear to be playing a significant role in developing the continental European research community, through co-authorship relations. This social relationship, in many cases, seems to arise from a prior role as $\mathrm{PhD}$ supervisor. These social links are facilitating the dissemination of research skills across the continent and beyond. Thus, UK researchers are contributing to the development of scholarly knowledge not only directly, but also through their academic links with non-UK researchers. 


\section{ENDNOTES}

${ }^{1}$ I use the term 'conventional' to refer to research that is not grounded in critical perspectives. I have eschewed the term 'mainstream' because 'critical accounting' is increasingly entering the mainstream outside the US.

${ }^{2}$ Several excellent reviews of major areas have appeared in recent years, although in the main these are written by US authors and focus on US research outputs.

${ }^{3}$ Of course its importance does vary across disciplines and research books have a key role in some disciplines.

${ }^{4} \mathrm{I}$ am grateful to an anonymous reviewer for drawing this point to my attention.

${ }^{5}$ This is classed as an interface journal by Beattie \& Goodacre (2004) - 50\% of articles are allocated to the accounting discipline and $50 \%$ to the finance discipline.

6 'UK researchers' are individuals who are affiliated, at the time of article publication, with an institution located in the UK.

${ }^{7}$ The geographic location of the co-authors were: Spain (4); Australia, Canada, Taiwan and the US, (2 each); Belgium, Cyprus, France, Germany, Indonesia, Jordan, Kuwait, Malaysia (1 each); and 2 papers with co-authors from more than one country (New Zealand and Hong Kong; and South Africa and Australia).

${ }^{8}$ Perfect markets exist where identical items command the same price in a perfectly competitive market; complete markets exist when all desired trades can be undertaken.

${ }^{9}$ The information perspective to accounting was pioneered by US researchers such as Demski, Feltham and Beaver.

${ }^{10}$ Walker (1997a) provides a slightly more dated review of clean surplus accounting models in MBAR.

${ }^{11}$ Residual income is defined as annual accounting profits minus an interest change on the book value of assets.

${ }^{12}$ The first advocate was Preinreich, writing in the 1930s.

${ }^{13}$ An excellent and brief review of the key features of Feltham-Ohlson modelling, and criticisms of it, can be found in Beaver (2002, pp.457-459).

${ }^{14}$ Defined as the change in book value of owners' equity plus dividends equals earnings.

${ }^{15}$ Note that the concept of residual income can be traced back to Peasnell (1982), Edwards \& Bell (1961) and earlier.

${ }^{16}$ For example, Germany is an environment where the focus is on lenders rather than equity investors; Switzerland is an environment where investors focus on dividends.

17 Note, however, that earlier studies had found that earnings have greater value relevance than cashflows, providing evidence of the value of accrual accounting (Ali \& Pope, 1995).

18 This paper is significant not only for its intellectual contribution, but because it is the only UKauthored paper on financial accounting to be published in one of the three leading accounting journals (Accounting Review, Journal of Accounting Research, and Journal of Accounting and Economics) during the period 1998-2002. The only other UK-authored paper was an auditing study by Lennox published in JAE in 2000.

${ }^{19}$ In 2001 the $J A E$ published a series of reviews of some of the main, economics-based strands of this literature.

${ }^{20}$ Verrecchia (2001), in his review of the disclosure literature, refers to the latter two strands as 'discretionary-based disclosure' and 'association-based disclosure' studies, respectively.

${ }^{21}$ Gray et al. (1995) identify decision-usefulness and positive accounting as alternative informing theories. They argue that the former is mis-specified and under-theorised, while the latter (with its reliance on market mechanisms) is inappropriate given the subject matter.

${ }^{22}$ The proxy used for political costs in early studies (size), is problematic and recent research has therefore tended to look at specific wealth transfers imposed by regulation.

${ }^{23}$ The list of research interests for each individual contained in the BAR Research Register was used to quantify the relative amount of financial accounting research undertaken in the UK. A simple head count is problematic for two reasons. First, many researchers' have interests in several areas. Secondly, it is often not a straightforward task to classify listed research interests as falling inside/outside the field of financial accounting. For this reason, the Register's own classification of research interests into 20 categories was used. This includes 'financial accounting and reporting' and 'market based accounting research' among the categories. Each researcher can have several entries. A count of the entries in the subject index shows that these two categories account for only $13.3 \%$ of the total number. 



\section{REFERENCES}

Acker, D., Horton, J. \& Tonks, I. (2002). 'Accounting standards and analysts' forecasts: the impact of FRS3 on analysts' ability to forecast EPS', Journal of Accounting and Public Policy, 21(3), pp. 193-217.

Adams, C.A. (2002). 'Internal organisational factors influencing corporate social and ethical reporting: beyond current theorising', Accounting, Auditing and Accountability Journal, 15(2), pp. 223250 .

Adams, C.A., Hill, W.-Y. \& Roberts, C.B. (1998). 'Corporate social reporting practices in Western Europe: legitimating corporate behaviour?' British Accounting Review, 30(1), pp. 1-21.

Aerts, W. (2001). 'Inertia in the attributional content of annual accounting narratives', European Accounting Review, 10(1), pp. 3-32.

AICPA (1994). Improving Business Reporting - A Customer Focus: Meeting the Information Needs of Investors and Creditors, Comprehensive Report of the Special Committee on Financial Reporting (The Jenkins Report), New York, NY, American Institute of Certified Public Accountants.

Akerlof, G.A. (1970). 'The market for "lemons": quality uncertainty and the market mechanism', Quarterly Journal of Economics, August, pp.488-500.

Al-Debie, M. \& Walker, M. (1999). 'Fundamental information analysis: an extension and UK evidence', British Accounting Review, 31(3), pp.261-280.

Ali, A. \& Pope, P. (1995). 'The incremental information content of earnings, funds flow and cash flow: the UK evidence', Journal of Business Finance and Accounting, 22(1), pp.19-34.

ASB (1999). Statement of Principles, London, Accounting Standards Board.

Ashton, D., Cooke, T. \& Tippett, M. (2003). 'An Aggregation Theorem for the valuation of equity under linear information dynamics', Journal of Business Finance and Accounting, 30(3\&4), pp. 413-440.

Bailey, D., Harte, G. \& Sugden, R. (2000). 'Corporate disclosure and the deregulation of international investment', Accounting, Auditing and Accountability Journal, 13(2), pp.197218.

Ball, R. \& Brown, P. (1968). 'An empirical evaluation of accounting income numbers', Journal of Accounting Research, 6(2), pp.159-178.

Ballas, A. \& Theoharakis, V. (2003). 'Exploring diversity in accounting through faculty journal perceptions, Contemporary Accounting Research, 20(4), pp.619-644..

Barker, R. (1998). 'The market for information - evidence from finance directors, analysts and fund managers', Accounting and Business Research, 29(1), Winter, pp.3-20.

Barker, R. (1999). 'The role of dividends in valuation models used by analysts and fund managers', European Accounting Review, 8(2), pp. 195-218. 
Barker, R. (2000). 'FRS3 and analysts' use of earnings', Accounting and Business Research, 30(2), pp. 95-109.

Barron, O.E., Kile, C.O. \& O'Keefe, T.B. (1999). 'MD\&A quality as measured by the SEC and analysts' earnings forecasts', Contemporary Accounting Research, 16(1), Spring, pp.75-109.

Barth, M.E., Beaver, W.H. \& Landsman, W.R. (2001). 'The relevance of the value-relevance literature for financial accounting standard-setting: another view', Journal of Accounting and Economics, 31(1-3), pp. 77-104.

Bartlett, S.A. \& Chandler, R.A. (1997). 'The Corporate Report and the private shareholder: Lee and Tweedie twenty years on', British Accounting Review, 29(3), pp. 245-261.

Beattie, V. (2002). 'Traditions of research in financial accounting.' In Ryan, B., Scapens, R.W. \& Theobald, M., Research Method \& Methodology in Finance \& Accounting, second edition, London, Thomson.

Beattie, V., Edwards, K. \& Goodacre, A. (1998). 'The impact of constructive operating lease capitalisation on key accounting ratios', Accounting and Business Research, 30(3), pp.233254.

Beattie, V. \& Goodacre, A. (2004). 'Publishing patterns within the UK accounting and finance academic community',. British Accounting Review, 36(1), pp.7-44.

Beattie, V. \& Jones, M.J. (1999). 'Do Australian graphs give a true and fair view?', Abacus, 35(1), pp. 46-76.

Beattie, V. \& Jones, M.J. (2000). 'Changing graph use in corporate annual reports: a time series analysis', Contemporary Accounting Research, 17(2), pp. 213-226.

Beattie, V. \& Jones, M.J. (2002). 'The impact of graph slope on rate of change judgments in corporate reports', Abacus, 38(2), pp. 177-199.

Beattie, V. \& Jones, M.J. (2003). 'Measurement distortion of graphs in corporate reports: an experimental study', Accounting, Auditing and Accountability Journal,, 15(4), pp. 546-564.

Beattie, V., McInnes, B. \& Fearnley, S. (2002). Through the Eyes of Management: A Study of Narrative Disclosures, Research Report, London, Institute of Chartered Accountants in England and Wales,

Beattie, V. \& Pratt, K. (2003). 'Issues concerning web-based business reporting: an analysis of the views of interested parties', British Accounting Review, 35(2), pp. 155-187..

Beattie, V. \& Pratt, K. (2002). Voluntary Annual Report Disclosures: What Users Want. Research Report, Edinburgh, The Institute of Chartered Accountants of Scotland..

Beaver, W.H. (2002). 'Perspectives on recent capital market research', The Accounting Review, 77(2), April, pp. 453-474.

Borgman, C.L. (ed.) (1990). Scholarly Communication and Bibliometrics, Newbury Park, California, Sage Publications. 
Botosan, C.A. (1997), 'Disclosure Level and the Cost of Equity Capital'. The Accounting Review, 72(3), pp. 323-349.

Breton, G. \& Taffler, R.J. (2001). 'Accounting information and analyst stock recommendation decisions: a content analysis approach', Accounting and Business Research, 31(2), pp. 91-101.

Bromwich, M. (1992). Financial Reporting, Information and Capital Markets, London, Pitman.

Bromwich, M. (2001). 'Angels and trolls: the ASB's statement of principles for financial reporting', British Accounting Review, 33(1), pp.47-72.

Bromwich, M. \& Walker, M. (1998). 'Residual income past and future', Management Accounting Research, 9(4), pp.391-419.

Capstaff, J., Paudyal, K. \& Rees, W. (1995). 'The accuracy and rationality of earnings forecasts by UK analysts', Journal of Business Finance and Accounting, 22(1), pp. 69-87.

Capstaff, J., Paudyal, K. \& Rees, W. (1999). 'The relative forecast accuracy of UK brokers', Accounting and Business Research, 30(1), pp. 3-16.

Capstaff, J., Paudyal, K. \& Rees, W. (2001). 'A comparative analysis of earnings forecasts in Europe', Journal of Business Finance and Accounting, 28(5/6), pp. 531-562.

Carmona, S., Gutiérrez, I. \& Cámara, M. (1999). 'A profile of European accounting research: evidence from leading research journals', European Accounting Review, 8(3), pp,463-480.

Charitou, A. \& Clubb, C. (1999). 'Earnings, cashflows and security returns over long return intervals: analysis and UK evidence', Journal of Business Finance and Accounting, 26(3/4), pp. 283-312.

Charitou, A., Clubb, C. \& Andreou, A.(2001). 'The effect of earnings permanence, growth, and firm size on the usefulness of cash flows and earnings in explaining security returns: empirical evidence for the UK', Journal of Business Finance and Accounting, 28(5/6), pp. 563-594.

Charitou, A., Neophytou, E. \& Charalambous, C. (2004). 'Predicting corporate failure: empirical evidence for the UK', European Accounting Review, 13(3), pp. 465-497.

Christensen, J.A. \& Demski, J.S. (2003). Accounting Theory: An Information Content Perspective, New York, McGraw-Hill.

Citron, D.B. (2001). 'The valuation of deferred taxation: evidence from the UK partial provision approach', Journal of Business Finance and Accounting, 28(7/8), pp. 821-852.

Clarkson, P.M., Kao, J.L. \& Richardson, G.D. (1999). 'Evidence that management discussion and analysis (MD\&A) is a part of a firm's overall disclosure package', Contemporary Accounting Research, 16(1), pp. 111-134.

Clatworthy, M. \& Jones, M.J. (2001). 'The effect of thematic structure on the variability of annual report readability', Accounting, Auditing \& Accountability Journal, 14(3), pp. 311-326. 
Collin, S.-O., Johansson, U., Svensson, K. \& Ulvenblad, P.-O. (1996). 'Market segmentation in scientific publications: research patterns in American vs European management journals', British Journal of Management, 7, pp.141-154.

Cooke, T. \& Tippett, M. (2000). 'Double entry bookkeeping, structural dynamics and the value of the firm', British Accounting Review, 32(3), pp. 261-288.

Core, J.E. (2001). 'A review of the empirical disclosure literature: discussion', Journal of Accounting and Economics, 31(1-3), pp. 441-456.

Crane, D. (1972). Invisible Colleges, Chicago, University of Chicago Press.

Craven, B.M. \& Marston, C.L. (1999). 'Financial reporting on the Internet by leading UK companies', European Accounting Review, 8(2), pp. 321-333.

Davison, J.E. (2001). 'Communication in corporate annual reports: a case study of antithesis in the pictures, chairman's statement and other material in Reuters 2000 annual report and review', Working Paper, Brunel University.

Dechow, P.M., Sloan, R.G. \& Sweeney, A.P. (1995). 'Detecting earnings management', The Accounting Review, 70(2), pp.193-225.

Diamond, D.W. (1985). 'Optimal release of information by firms', Journal of Finance, 40(4), September, pp.1071-1094.

Dumontier, P. \& Raffournier, B. (2002). 'Accounting and capital markets: a survey of the European evidence', European Accounting Review, 11(1), pp.119-151.

Edwards, E. \& Bell, P. (1961). The Theory and Measurement of Business Income. Berkeley, CA, University of California Press.

FASB (2001) Business and Financial Reporting, Challenges from the New Economy. Special Report, Financial Accounting Standards Board.

Fearnley, S., Hines, T., McBride, K. \& Brandt, R. (2002). 'The impact of the Financial Reporting Review Panel on aspects of the independence of auditors and their attitudes to compliance in the UK', British Accounting Review, 34(2), pp. 109-139.

Feltham, G. \& Ohlson, J. (1995). 'Valuation and clean surplus accounting for operating and financial activities', Contemporary Accounting Research, 11(2), pp. 689-731.

Forker, J. (2000). 'Models of the reporting entity and accounting for equity-based consideration', Accounting and Business Research, 31(1), pp. 3-17.

Friedman, A.L. \& Miles, S. (2001). 'Socially responsible investment and corporate social and environmental reporting in the UK: an exploratory study', British Accounting Review, 33(4), pp. 523-548.

Garrod, N. \& Hadi, M. (1998). 'Investor response to cashflow information', Journal of Business Finance and Accounting, 25(5/6), pp. 613-630. 
Garrod, N. \& Rees, W. (1998). 'International diversification and firm value', Journal of Business Finance and Accounting, 25(9/10), pp. 1255-1281.

Gibbins, M., Richardson, A. \& Waterhouse, J. (1990). 'The management of corporate financial disclosure: opportunism, ritualism, policies, and processes', Journal of Accounting Research, 28(1), pp. 121-143.

Giner, B. \& Rees, W. (2001). 'On the asymmetric recognition of good and bad news in France, Germany and the United Kingdom', Journal of Business Finance and Accounting, 28(9/10), pp. 1285-1332.

Gore, P., Taib, F.M. \& Taylor, P.A. (2000). 'Accounting for goodwill: an examination of factors influencing management preferences', Accounting and Business Research, 30(3), pp. 213225 .

Gray, R. (2002). 'The social accounting project and Accounting Organizations and Society privileging engagement, imaginings, new accountings and pragmatism over critique?', Accounting Organizations and Society, 27(7), pp. 687-708.

Gray, R., Kouhy, R. \& Lavers, S. (1995). 'Corporate social and environmental reporting: a review of the literature and a longitudinal study of UK disclosure', Accounting, Auditing and Accountability Journal, 8(2), pp.47-77.

Gregory, A. (2000). 'Motives underlying the method of payment by UK acquirers: the influence of goodwill', Accounting and Business Research, 30(3), pp. 227-240.

Grinyer, J. (1985). 'Earned economic income: a theory of matching', Abacus, March, pp.43-54.

Healy, P.M. \& Palepu, K.G. (2001). 'Information asymmetry, corporate disclosure, and the capital markets: a review of the empirical disclosure literature', Journal of Accounting and Economics, 31(1-3), pp. 405-440.

Healy, P.M. \& Wahlen, J.M. (1999). 'A review of the earnings management literature and its implications for standard-setting', Accounting Horizons, 13(4), pp. 365-383.

Helliar, C.V. \& Gray, R.H. (2000). The British Accounting Review Research Register 2000, $9^{\text {th }}$ ed, London, Academic Press.

Hines, T., McBride, K., Fearnley, S. \& Brandt, R. (2001). 'We're off to see the wizard', Accounting, Auditing and Accountability Journal, 14(1), pp. 53-84.

Hodgkinson, L. (2001). 'Analysts' forecasts and the broker relationship', Journal of Business Finance and Accounting, 28(7/8), pp.943-962.

Holland, J. (1998a). 'Private disclosure and financial reporting', Accounting and Business Research, 28(4), pp. 255-269.

Holland, J. (1998b). 'Private voluntary disclosure, financial intermediation and market efficiency', Journal of Business Finance and Accounting, 25(1/2), pp. 29-68.

Holland, J. (2001). 'Financial institutions, intangibles and corporate governance', Accounting, Auditing and Accountability Journal, 14(4), pp. 497-529. 
Holland, K. (1998). 'Accounting policy choice: the relationship between corporate tax burdens and company size', Journal of Business Finance and Accounting, 25(3/4), pp. 265-288.

Holthausen, R.W. \& Watts, R.L. (2001). 'The relevance of the value-relevance literature for financial accounting standard-setting', Journal of Accounting and Economics, 31(1-3), pp.375.

Hussain, S. (1998). 'Lead indicator models and UK analysts' earnings forecasts', Accounting and Business Research, 28(4), pp. 271-280.

Hussain, S. (2000). 'Simultaneous determination of UK analyst following and institutional ownership', Accounting and Business Research, 30(2), pp. 111-124.

Hussain, S. (2002). 'UK brokers' characteristics: does size matter?', Accounting and Business Research, 32(3), pp. 153-170.

Hussainey, K., Schleicher, T. \& Walker, M. (2003). 'Undertaking large-scale disclosure studies when AIMR-FAF ratings are not available: the case of prices leading earnings', Accounting and Business Research, 33(4), pp.275-294.

Jensen, R.E. and Xiao, J.Z. (2001). 'Customised financial reporting, networked databases and distributed file sharing', Accounting Horizons, September, 15(3), pp. 209-222.

Jones, J.J. (1991). 'Earnings management during import relief investigations', Journal of Accounting Research, 29, pp.193-228.

Kothari, S.P. (2001). 'Capital markets research in accounting', Journal of Accounting and Economics, 31(1-3), pp.105-231.

Levitt, A. (1998). 'The numbers game', Speech delivered at the New York Center for Law and Business, $28^{\text {th }}$ September.

Libby, R., Bloomfield, R. \& Nelson, M.W. (2002). 'Experimental research in financial accounting', Accounting, Organizations and Society, 27(8), pp. 775-810.

Lin, S. (2002). 'The association between analysts' forecast revisions and earnings components: the evidence of FRS 3', British Accounting Review, 34(1), pp. 1-26.

Lin, S. \& Walker, M. (2000). 'FRS3 earnings, Headline earnings, and accounting-based valuation models', Accounting and Business Research, 30(4), pp. 299-306.

Lin, Y.C. \& Peasnell, K.V. (2000). 'Fixed asset revaluation and equity depletion in the UK', Journal of Business Finance and Accounting, 27(3/4), pp. 359-394.

Lukka, K. \& Kasanen, E. (1996). 'Is accounting a global or a local discipline? Evidence from major research journals', Accounting, Organizations and Society, 21(7/8), pp. 755-773.

Mayer, R.E. (1987). Educational Psychology: A Cognitive Approach. Boston, Little, Brown and Company. 
McNichols, M.F. (2000). 'Research design issues in earnings management studies', Journal of Accounting and Public Policy, 19, pp. 313-345.

Meeks, G. \& Meeks, J.G. (2001). 'The loser's curse: accounting for the transaction costs of takeover and the distortion of takeover motives', Abacus, 37(3), pp. 389-400.

Miles, S. \& Nobes, C. (1998). 'The use of foreign accounting data in UK financial institutions', Journal of Business Finance and Accounting, 25(3/4), pp. 309-328.

Mullins, N.C. (1973). Theories and Theory Groups in Contemporary American Sociology. New York, Harper and Row.

Neophytou, E. \& Mar Molinero, C. (2004). 'Predicting corporate failure in the UK: a multidimensional scaling technique', Journal of Business Finance and Accounting, 31(5\&6), pp. 677-710.

O’Hanlon, J. (1998). 'The articulation of returns and accounting-related variables when returns lead earnings: UK evidence', Journal of Business Finance and Accounting, 25(9\&10), pp.11631201.

O'Hanlon, J. \& Peasnell, K. (1998). 'Wall Street's contribution to management accounting: the Stern Stewart EVA® financial management system', Management Accounting Research, 9(4), pp.421-444.

O'Hanlon, J. \& Peasnell, K. (2002). 'Residual income and value-creation: the missing link', Review of Accounting Studies, 7(2/3), pp.229-245.

O'Hanlon, J. \& Pope, P. (1999), 'The value-relevance of UK dirty surplus accounting flows', British Accounting Review, 31(4), pp.459-482.

O'Hanlon, J. \& Steele, A. (2000). 'Estimating the equity risk premium using accounting fundamentals', Journal of Business Finance and Accounting, 27(9/10), pp. 1051-1084.

Ohlson, J. (1995). 'Earnings, book values and dividends in equity valuation', Contemporary Accounting Research, 11(2), pp. 661-687.

Otley, D. \& The Accounting and Finance RAE 2001 Panel (2002), 'British research in accounting and finance (1996-2000): the 2001 research assessment exercise', British Accounting Review, 34(4), pp.387-417.

Page, M. \& Spira, L. (1999). 'The conceptual underwear of financial reporting', Accounting, Auditing and Accountability Journal, 12(4), pp. 489-501.

Peasnell, K. (1982). 'Some formal connections between economic values and yields, and accounting numbers', Journal of Business Finance and Accounting, 9, pp. 361-381.

Peasnell, K.V., Pope, P.F. \& Young, S. (2000a). 'Detecting earnings management using crosssectional abnormal accruals models', Accounting and Business Research, 30(4), pp. 313326.

Peasnell, K.V., Pope, P.F. \& Young, S. (2000b). 'Accrual management to meet earnings targets: UK evidence pre- and post-Cadbury', British Accounting Review, 32(4), pp. 415-445. 
Peasnell, K.V., Pope, P.F. \& Young, S. (2001). 'The characteristics of firms subject to adverse rulings by the Financial Reporting Review Panel', Accounting and Business Research, 31(4), Autumn, pp. 291-311.

Pellicer, M. \& Rees, W. (1999). 'Regularities in the equity price response to earnings announcements in Spain', European Accounting Review, 8(4), pp.585-607.

Pierce-Brown, R. \& Steele, T. (1999). 'The economics of Accounting for Growth', Accounting and Business Research, 29(2), pp. 157-173.

Pope, P. \& Walker, M. (1999). 'International differences in the timeliness, conservatism and classification of earnings and earnings announcements', Journal of Accounting Research, 37(supplement), pp. 53-87.

Power, M. (2001). 'Imagining, measuring and managing intangibles', Accounting, Organizations and Society, 26(7/8), pp. 691-693.

Preston, A.M. \& Young, J.J. (2000). 'Constructing the global corporation and corporate constructions of the global: a picture essay', Accounting, Organizations and Society, 25(4/5), pp. 427-449.

Roslender, R. \& Fincham, R. (2001). 'Thinking critically about intellectual capital accounting', Accounting, Auditing and Accountability Journal, 14(4), pp. 383-398.

Rudner, R. (1966). Philosophy of Social Science. Englewood Cliffs, NJ, Prentice-Hall.

Schleicher, T. \& Walker, M. (1999). 'Share price anticipation of earnings and management's discussion of operations and financing', Accounting and Business Research, 29(4), pp. 321335.

Shah, A. (1998). 'Exploring the influences and constraints on creative accounting in the United Kingdom', European Accounting Review, 7(1), pp. 83-104.

Smith, M. \& Taffler, R.J. (2000). 'The chairman's statement: a content analysis of discretionary narrative disclosures', Accounting, Auditing and Accountability Journal, 13(5), pp. 624-646.

Solomon, J., Solomon, A., Norton, S.D. \& Joseph, N.L. (2000). 'A conceptual framework for corporate risk disclosure emerging from the agenda for corporate governance reform', British Accounting Review, 32(4), pp. 447-478.

Stark, A.W. \& Thomas, H.M. (1998). 'On the empirical relationship between market value and residual income in the U.K.', Management Accounting Research, 9(4), pp.445-460.

Strong, N. and Walker, M. (1987). Information and Capital Markets, Oxford, Basil Blackwell.

Sydserff, R. \& Weetman, P. (1999). 'A texture index for evaluating accounting narratives: an alternative to readability formulas', Accounting, Auditing and Accountability Journal, 12(4), pp. 459-488.

Taffler, R.J. (1983). 'The assessment of company solvency and performance using a statistical model', Accounting and Business Research, 15(52), pp. 295-308. 
Trigueiros, D. \& Taffler, R. (1996). 'Neural networks and empirical research in accounting', Accounting and Business Research, 26(4), pp. 347-355.

Verrecchia, R.E. (1983). 'Discretionary disclosure', Journal of Accounting and Economics, 5, December, pp.179-194.

Verrecchia, R.E. (2001). 'Essays on disclosure', Journal of Accounting and Economics, 31.

Walker, M. (1997a). 'Clean surplus accounting models and market based accounting research: a review', Accounting and Business Research, 27(4), pp. 341-355.

Walker, M. (1997b). The Economics of Corporate Financial Communication, Occasional Research Paper No.19, London, Association of Chartered Certified Accountants.

Watts, R.L. \& Zimmerman, J.L. (1986). Positive Accounting Theory, Englewood Cliffs, NJ, Prentice Hall.

Weetman, P. (2001). 'Controlling the standard-setting agenda: the role of FRS3', Accounting, Auditing and Accountability Journal, 14(1), pp. 85-109.

Woodward, D., Edwards, P. \& Birkin, F. (2001). 'Some evidence on executives' views of corporate social responsibility', British Accounting Review, 33(3), pp. 357-397.

Woolgar, S. (1988). Knowledge and Reflexivity: New Frontiers in the Sociology of Knowledge, Beverly Hills, CA, Sage Publications.

Young, S. (1998). 'The determinants of managerial accounting policy choice: further evidence for the UK', Accounting and Business Research, 28(2), pp. 131-143.

Young, S. (1999). 'Systematic measurement error in the estimation of discretionary accruals: an evaluation of alternative modelling procedures', Journal of Business Finance and Accounting, 26(7/8), pp. 833-862. 
Table 1: Incidence of Financial Accounting Articles across Popular Outlets for UK Authors

\begin{tabular}{|l|r|r|r|r|r|r|}
\hline & & & & \multicolumn{3}{|c|}{$\begin{array}{c}\text { Proportion of FA } \\
\text { articles authored in: }\end{array}$} \\
\cline { 5 - 8 } Journal & Total no. & No. of FA & Proportion of & & & \multicolumn{2}{|c|}{$\begin{array}{c}\text { Rest of } \\
\text { world }\end{array}$} \\
\hline EAR & 133 & 39 & 0.29 & 0.31 & 0.00 & 0.69 \\
\hline BAR & 76 & 34 & 0.45 & 0.71 & 0.00 & 0.29 \\
\hline JBFA & 224 & 60 & 0.27 & 0.43 & 0.37 & 0.20 \\
\hline ABR & 85 & 39 & 0.46 & 0.69 & 0.03 & 0.28 \\
\hline AAAJ & 118 & 36 & 0.31 & 0.39 & 0.03 & 0.58 \\
\hline AOS & 164 & 24 & 0.15 & 0.29 & 0.33 & 0.38 \\
\hline Ab & 69 & 29 & 0.42 & 0.17 & 0.31 & 0.52 \\
\hline Total & 869 & 261 & 0.30 & 0.44 & 0.16 & 0.40 \\
\hline
\end{tabular}


Table 2: Number of Studies in Specific Research Areas (1998-2002)

\begin{tabular}{|l|r|r|r|r|}
\hline \multicolumn{1}{|c|}{ Research area } & \multicolumn{1}{c|}{$\begin{array}{c}\text { No. of } \\
\text { studies }\end{array}$} & \multicolumn{1}{c|}{$\%$} & \multicolumn{1}{c|}{$\begin{array}{c}\text { No. of studies } \\
\text { with UK author }\end{array}$} & \multicolumn{1}{c|}{$\%$} \\
\hline Normative & 10 & 3.8 & 5 & 4.3 \\
\hline Financial BAR & 12 & 4.6 & 4 & 3.5 \\
\hline MBAR & 65 & 25.0 & 23 & 26.1 \\
\hline $\begin{array}{l}\text { Disclosure, inc. CSR \& } \\
\text { intangibles }\end{array}$ & 61 & 23.4 & 9 & 7.8 \\
\hline $\begin{array}{l}\text { Other business reporting } \\
\text { issues(narratives, graphs } \\
\text { and Internet) }\end{array}$ & 15 & 5.7 & & \\
\hline Earnings management & 16 & 6.1 & 5 & 4.3 \\
\hline Accounting choice & 8 & 3.1 & 6 & 5.2 \\
\hline Economic consequences & 4 & 1.5 & 3 & 2.6 \\
\hline Failure prediction & 12 & 4.6 & 1 & 0.9 \\
\hline Standard setting & 14 & 5.4 & 7 & 6.1 \\
\hline Other & 44 & 16.8 & 22 & 19.1 \\
\hline Total & $\mathbf{2 6 1}$ & $\mathbf{1 0 0 . 0}$ & $\mathbf{1 1 5}$ & $\mathbf{1 0 0 . 0}$ \\
\hline
\end{tabular}


Table 3: Number of Studies using Specific Research Methods (1998-2002)

\begin{tabular}{|l|r|r|}
\hline \multicolumn{1}{|c|}{ Research area } & \multicolumn{1}{c|}{$\begin{array}{c}\text { No. of } \\
\text { studies }\end{array}$} & \multicolumn{1}{|c|}{$\%$} \\
\hline Reasoned argument & 31 & 11.9 \\
\hline Analytical modelling (may include empirical element) & 16 & 6.1 \\
\hline $\begin{array}{l}\text { Archival: financial statement, company report, market and } \\
\text { analyst forecast data }\end{array}$ & 132 & 50.6 \\
\hline Content analysis (may include archival) & 20 & 7.7 \\
\hline Case study (mix of documentary, survey and archival) & 12 & 4.6 \\
\hline Interview & 12 & 4.6 \\
\hline Questionnaire & 4 & 1.5 \\
\hline Survey mixed (with participant observation, archival or & 7 & 2.7 \\
\hline experimental) & 11 & 4.3 \\
\hline Experimental & 5 & 1.9 \\
\hline Literature review & 4 & 1.5 \\
\hline Documentary evidence & 3 & 1.1 \\
\hline Simulation & 4 & 1.5 \\
\hline Other (protocol analysis, meta-analysis) & $\mathbf{2 6 1}$ & $\mathbf{1 0 0 . 0}$ \\
\hline Total & & \\
\hline
\end{tabular}

